\title{
Nyt styre i Mauretanien
}

Gunna Funder Hansen

\section{I begyndelsen af august i år blev præsidenten i Mauretanien væltet ved et militærkup. Hvad var baggrunden for kuppet? Hvordan reagerede det internationale samfund og den mauretanske befolkning? Og hvad betyder kuppet for Maureta- niens fremtid?}

Militærkuppet i Mauretanien 3. august 2005 var på samme tid nærmest forudsigeligt og ganske uventet:

Den nu væltede præsident, Ahmad Ould Taya, kom selv til magten ved et militærkup i 1984 og var i sin regeringsperiode udsat for utallige kupforsøg. Han var en upopulær leder, der som så mange andre afrikanske herskere favoriserede sin egen klan økonomisk og politisk og aldrig formåede at skabe en positiv udvikling i landets elendige økonomi. At nogen ønskede ham afsat, var derfor ikke spor overraskende.

Men efter at et voldsomt kupforsøg i august 2003 var meget tæt på at lykkes, havde Ould Taya imidlertid strammet grebet om især de islamiske oppositionsgrupper og nærmest barrikaderet sig fra omverden, og han drev landet som et hårdkogt diktatur. Derfor var det nok de færreste der forventede, at han netop nu ville kunne væltes.

At kuppet denne gang lykkedes skyldes utvivlsomt, at kuplederen kom fra den tidligere præsidents inderkreds. Den nye præsident, Ely Ould Mohammad Vall, var således medvirkende til at bringe Ould Taya til magten i 1984, ligesom han i Ould Tayas regeringsperiode beklædte centrale poster i militæret og sikkerhedstjenesten.

\section{Populært magtskifte}

En yderligere medvirkende årsag til, at kuppet gik så glat igennem, var formentlig, at det forløb ganske ublodigt: Ould Taya, som normalt var yderst forsigtig med at forlade sin residens i hovedstaden Nouakchott, 
var taget til kong Fahds begravelse i Saudi Arabien, og i hans fravær overtog Ould Vall stille og roligt regeringskontoret, bad den tidligere præsidentfrue om at pakke en kuffert og sendte bud til sin forgænger om ikke at vende hjem - ganske som en rigtig gentleman.

Samtidig løslod han et stort antal politiske fanger, indkaldte de vigtigste oppositionsgrupper til forhandlinger og lovede, at der vil blive afholdt valg, hvori det vil stå dem frit for at deltage. Resultatet var, at oppositionen - i stedet for at forsøge at udnytte situationen til selv at få foden inden for i paladset - forholdt sig i ro.

Og ikke nok med det - knap to uger efter kuppet annoncerede en koalition bestående af 10 mauretanske oppositionspartier og civile organisationer, at de varmt støtter magtskiftet, som "en historisk chance for at rekonstruere den mauretanske nation", og at det "bør føre til etableringen af en retsstat karakteriseret af god regeringsførelse og pluralistisk demokrati”.

Også hvad angår den internationale scene udviste den nye leder stor tæft. Både USA og den tidligere kolonimagt Frankrig, der er Mauretaniens vigtigste allierede i Vesten, samt Den Afrikanske Union blev indbudt til forhandlinger. Og de obligatoriske fordømmelser, som blev offentliggjort umiddelbart efter kuppet, blev meget hurtigt nedtonet:

Mens Frankrig blot valgte at holde meget lav profil, udtalte en talsmand fra det amerikanske udenrigsministerium allerede en uge efter kuppet, at man ikke længere fastholder kravet om genindsættelse af den væltede præsident, men derimod samarbejder med det nye styre om hurtigst muligt at få afholdt frie valg.

Den Afrikanske Union, der straks havde suspenderet Mauretanien fra sit unionsråd, fastholdt suspensionen på baggrund af en "principiel afstandtagen" til militærkup generelt, men unionens talsmand i sagen, den nigerianske udenrigsminister, Oluyemi Adeniji, udtalte få dage efter magtovertagelsen, at suspensionen kan ophæves, når der etableres et demokratisk styre, og at "der er forhold i situationer som denne, som gør en umiddelbar genindsættelse af den tidligere præsident meget upraktisk".

Meget nærmere en international blåstempling af et statskup kan man næsten ikke komme.

\section{Hvorfor nu?}

Ud over denne næsten overvældende accept fra både lokale oppositionsgrupper og det internationale samfund, vakte magtskiftet tilsyneladende begejstring i den brede befolkning, idet tusinder af mauretaniere lige efter at kuppet var annonceret, gik på gaden og demonstrerede deres støtte til kupmagerne.

Umiddelbart kan det virke overra- 
skende, at et tronskifte inden for magtens egne cirkler får så varm en velkomst. Men i lyset af Mauretaniens nuværende situation er der grund til at tro, at magtskiftet kan få afgørende betydning for den mauretanske befolkning i fremtiden:

Mauretanien er i dag et af verdens fattigste lande. Landets BNP pr. indbygger er under en tredjedel af, hvad det er i Marokko, der er det fattigste af de øvrige nordafrikanske lande, og næsten $30 \%$ af befolkningen lever for under $1 \$$ og $70 \%$ for under $2 \$$ om dagen. Men fremtiden ser måske lysere ud for mauretanierne, for inden for de senere år har man opdaget, at landet råder over forholdsvis betydelige oliereserver, og flere internationale selskaber har påbegyndt investeringer i udvinding af disse.

På den baggrund forventes Mauretanien at blive blandt de største olieeksportører i Afrika fra 2006, hvilket kan føre til, at landet får et økonomisk boom på samme måde som det skete i Tunesien mellem 1980 og 1990, hvor udvindingen af de tunesiske olieressourcer var på sit højeste. Ikke mindst på grund af de nuværende høje oliepriser, ser fremtiden således lovende ud.

I lyset af denne forventede forestående positive udvikling er der ingen tvivl om, at der i Mauretanien har været udbredt ængstelse over, hvordan Ould Taya ville forvalte den nye velstand. Hans generelle regeringsførelse kunne udmærket give anledning til bekymring for, hvorvidt den brede befolkning overhovedet ville få del i ressourcerne.

Til gengæld synes koalitionen af tidligere oppositionspartier at have stor tillid til Ould Vall - i hvert fald udtrykker de tillid til, at han snarest etablerer en overgangsregering, der kan stå for udviklingen af en ny forfatning, der skal vedtages ved folkeafstemning og garantere de fundamentale menneskerettigheder, stabilitet og lighed for alle etniske grupper.

Det er umiddelbart vanskeligt at sætte fingeren på, præcis hvad denne tillid bunder i, men Ould Vall beskrives generelt som lynende intelligent og som en meget karismatisk og charmerende personlighed, og en udbredt personlig tiltro til Ould Valls lederevner og politiske motiver kan naturligvis have betydning.

\section{De arabiske naboer}

Mens både den lokale opposition og de vestlige allierede altså nærmest falder på halen over den nye mauretanske førstemand, er det mere uklart, hvilken rolle kuppet spiller i regional sammenhæng.

Mauretaniens forhold til de nordlige nabolande afspejles især i samarbejdet - eller mangel på samme i den Maghreb-arabiske union (UMA), der blev etableret 1989 med henblik på at fremme politisk og $\varnothing$ konomisk samarbejde i regionen. UMA består af Mauretanien, Marok- 
ko, Tunesien, Algeriet og Libyen. Men samarbejdet har altid været særdeles konfliktfyldt.

Den primære konflikt består i mellemstatslige uoverensstemmelser: For Marokko og Algeriet har spørgsmålet om Vestsahara løbende umuliggjort en reel tilnærmelse. Marokko, som annekterede Vestsahara i 1975, undlader fortsat at gennemføre den folkeafstemning om Vestsaharas fremtid, som allerede i 1991 blev planlagt efter pres fra FN, mens Algeriet både huser og åbent støtter oprørsbevægelsen Polisario, der kæmper for Vestsaharas selvstændighed.

Samtidig har der i de senere år været særdeles kold luft mellem Mauretanien og Libyen, hvilket først og fremmest har været affødt af, at Mauretanien siden 1984 har etableret meget tætte relationer til både Israel og USA, ligesom den nu væltede mauretanske præsident har beskyldt Gaddafi for at støtte det nævnte kupforsøg mod ham i 2003.

Endvidere foregår der tydeligvis en vis rivalisering mellem landene $\mathrm{i}$ UMA i relation til, hvem der har bedst forbindelser til de vigtigste samarbejdspartnere i Vesten. Især Marokko og Algeriet kæmper løbende om franskmændenes og amerikanernes gunst, som har afgørende betydning i relation til parternes uenighed om Vestsahara.

I øjeblikket synes Marokko i den henseende at ligge lunt i svinget: Mens den manglende stabilitet i Al- geriet, hvor de islamiske grupperinger fortsat formår at spille en rolle, ikke gavner forholdet til de vestlige parter, har Marokkos konge, Mohammad VI, med sine reformer skabt sig et godt navn, og både amerikanerne og franskmændene forholder sig passivt til Marokkos manglende initiativ til at gennemføre den bebudede folkeafstemning om Vestsaharas fremtid. Denne passivitet tolkes i hvert fald af algerierne som opbakning til Marokko.

Hvad angår de øvrige lande, spiller Tunesien som stabil lilleputstat en mindre væsentlig rolle i den interne rivalisering. Libyen kører sit eget løb som international outsider, men har dog siden Saddam Husseins fald vist bemærkelsesværdige tilnærmelser til Washington. Mauretanien har som regionens fattiglem formået at tiltrække væsentlige bistandsressourcer fra både Frankrig og IMF og kunne med et tilskud fra IMF's initiativ for stærkt forgældede lande (HICP) i 2002 nedskrive sin udlandsgæld med næsten $50 \%$.

Landets økonomi er fortsat så svagt udviklet, at det ikke udgør nogen væsentlig konkurrent i forhold til de arabiske nabolande, men dette kan med de nævnte olieressourcer let ændre sig i løbet af en overskuelig årrække, og Mauretanien kan dermed komme til at spille en langt væsentligere rolle i det regionale samarbejde og dermed forrykke magtbalancen i de mellemstatslige konflikter i regionen. 


\section{Fremtidsperspektiver}

Mauretaniens fremtid afhænger i høj grad af, hvordan den nye situation forvaltes, hvis oliepengene rent faktisk begynder at strømme. Gode forbindelser til nabolandene og Frankrig vil være afgørende for, om landet får stabile handelspartnere, der kan sætte skub i den økonomiske udvikling inden for de øvrige sektorer.

I den sammenhæng kan det få betydning, hvordan Ould Vall vælger at forholde sig til den tidligere meget tætte alliance med Israel, som hans forgænger etablerede. Et farvel til alliancen vil kunne forbedre forholdet til flere arabiske stater betragteligt, mens det sandsynligvis ikke vil kompromittere det tætte forhold til Frankrig, der må betegnes som den primære vestlige interessent i Maghreb-området. Forholdet til USA vil muligvis være mere udsat, men der er heller ikke på nuværende tidspunkt handelsrelationer mellem USA og Mauretanien, og såfremt olieeventyret realiseres, vil der i mindre grad være behov for amerikansk opbakning formidlet gennem IMF og Verdensbanken.

I relation til Marokko har Ould Vall gode muligheder for at opbygge en stærk alliance, idet han har taget sin militære uddannelse i Marokko og derigennem utvivlsomt har værdifulde private forbindelser, ligesom han i løbet af sin militærtjeneste har været personligt involveret i bekæmpelsen af Polisario på den mauretanske side. Og hvis alliancerne med både Frankrig og Marokko er i orden, spiller et anstrengt forhold til Algeriet formentlig en mindre rolle.

Desuden er det naturligvis afgørende for Mauretaniens fremtid, om Ould Vall rent faktisk har reelle hensigter om at gennemføre de politiske reformer, han har lovet, og om han formår at styre uden om alvorlige splittelser i det militære råd, der lige nu er sat til at styre landet.

Endelig må man indse, at det vil være noget nær enestående, hvis Mauretanien undgår den skæbne, der tidligere er overgået så mange andre afrikanske stater, hvor nye, selvbestaltede ledere har proklameret en ny og lysere fremtid: At korruption og nepotisme simpelt hen undergraver de bebudede politiske reformer, så befolkningen igen står tilbage med sorteper.

Gunna Funder Hansen er Ph.d. og adjunkt ved Center for Mellemøststudier, Syddansk Universitet. 